\title{
Democracy, Public Expenditures, and the Poor
}

\section{Philip Keefer and Stuti Khemani}

\author{
Development Research Group \\ The World Bank \\ 1818 H Street, N.W. \\ Washington, DC 20433 \\ pkeefer@worldbank.org \\ skhemani@worldbank.org.
}

World Bank Policy Research Working Paper 3164, November 2003

The Policy Research Working Paper Series disseminates the findings of work in progress to encourage the exchange of ideas about development issues. An objective of the series is to get the findings out quickly, even if the presentations are less than fully polished. The papers carry the names of the authors and should be cited accordingly. The findings, interpretations, and conclusions expressed in this paper are entirely those of the authors. They do not necessarily represent the view of the World Bank, its Executive Directors, or the countries they represent. Policy Research Working Papers are available online at http:/ / econ.worldbank.org.

This paper was originally prepared as a background study for the World Development Report 2004: Making Services Work for Poor People. Support and comments from the WDR team, and especially from Shekhar Shah, are gratefully acknowledged. 


\begin{abstract}
Countries vary systematically with respect to the incentives of politicians to provide broad public goods and to reduce poverty. Even in developing countries that are democracies, politicians often have incentives to divert resources to political rents and to private transfers that benefit a few citizens at the expense of many. These distortions can be traced to imperfections in political markets that are greater in some countries than in others. We review the theory and evidence on the impact of incomplete information of voters, the lack of credibility of political promises, and social polarization, on political incentives. We argue that the effects of these imperfections are large but insufficiently integrated into the design of policy reforms aimed at improving public good provision and reducing poverty.
\end{abstract}

\title{
Contents
}

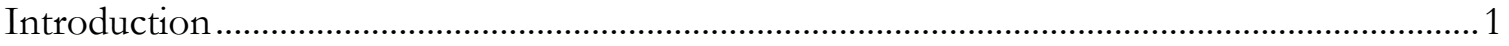

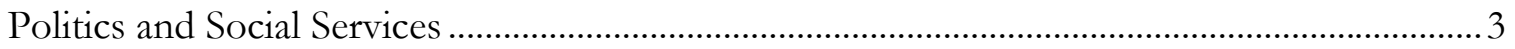

When Does Political Competition Lead to the Optimal Provision of Public Goods?.............. 5

The Impact of Imperfect Information on the Provision of Social Services to the Poor .......... 9

Social Polarization and Provision of Services to the Poor.............................................................14

Credibility and the Provision of Social Services ............................................................................. 16

The Credibility of Political Promises and the Impact of Clientelism on Social Service

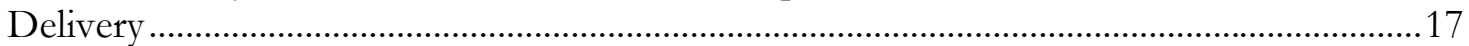

Horizon Problems and Credibility ...................................................................................19

The Dynamics of Political Competition and Provision of Social Services: Uttar Pradesh

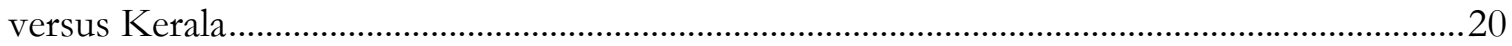

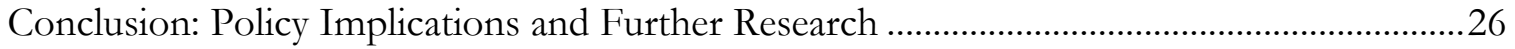

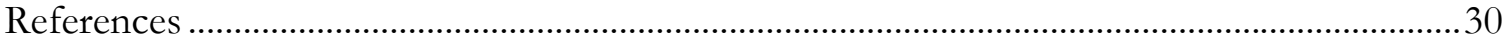




\section{Introduction}

One way in which governments can accelerate economic development is through their decisions regarding public expenditures. Allocated appropriately, public expenditures can overcome market failures that exacerbate poverty, such as the inability of the poor to borrow for education, their lack of information about preventive health care, or the externalities that exacerbate public health hazards to which the poor are most exposed. However, distortion and misallocation of public expenditures are common and often undermine development. Public expenditures flow to wage bills for bulky state administrations, to farm subsidies absorbed by the wealthiest farmers, or to public works projects with limited public utility, all at the expense of quality public services.

Misallocation has persisted despite a sea change in the way in which governments are selected and remain in office. From 1990 to 2000, the number of countries governed by officials elected in competitive elections rose from 60 to $100 .{ }^{1}$ A large fraction of voters in many of these countries are low income, if not poor in the strictest and most technical sense of the word. Democratization might be expected to benefit these voters. However, policymakers in poor democracies regularly divert expenditures away from those areas that most benefit the poor, or fail to implement policies that improve those services from which the poor are known to benefit disproportionately.

In most countries, the distribution of income is skewed to the right-towards the higher end of the income spectrum - so that the income of the median voter is less than the average income of all voters. Under these circumstances, government should be larger and social services should be correspondingly more extensive (Meltzer and Richard 1981). However, this prediction actually exacerbates the puzzle of why many countries severely under-provide social services, since it is in many countries where the poor are the median voters that social services are often the most woeful. Moreover, there is little evidence that redistribution is greater in countries with greater income inequality (Knack and Keefer 1997). There are numerous imperfections in political markets that help to explain this puzzle. In this paper, we review the theory and evidence on the impact of political market imperfections, and develop the implications of these findings for the structure and design of policy interventions meant to improve the allocation of resources.

The Millennium Development Goals and many efforts around the world to "empower" the poor, whether through devolved decisionmaking or through participatory budgeting, are all responses to these failures of government expenditure policies. These efforts have generally not explicitly addressed the political market imperfections that have

${ }^{1}$ According to the number of countries reported in Beck and others (2001), Database of Political Institutions, as having competitive elections for executive and legislative office (EIEC and LIEC equal to seven). 
distorted political incentives to serve the poor. In this paper, we focus on three political market imperfections that we argue are particularly important in distorting political incentives to provide high quality public services: lack of information among voters about politician performance; social fragmentation among voters manifested as identity-based voting; and lack of credibility of political promises to citizens. We show that existing efforts to improve the quality of public policy towards the poor may fall far short of achieving their goals unless they are expanded to address specifically these imperfections.

One difficult conclusion that we reach is that broad public services most important to the poor-health and education — are also the services most vulnerable to these three distortions of the political marketplace. It is especially difficult for voters to assess the quality and efficiency of service provision and to evaluate the responsibility of specific political actors for service breakdowns. By the same token, political competitors find it especially difficult to make credible promises about service provision. Moreover, politicians in many countries can only make credible promises to narrow groups of voters. For these voters, it may be politically more efficient to promise narrow targetable goods, such as infrastructure provision, than it is to promise improvements in broad public services. Social fragmentation in the electorate exacerbates these problems of voter coordination in determining reward and punishment based upon political actions towards the quality of public services. To the extent that in developing countries, poor voters are more likely to vote in uninformed ways, being susceptible to campaign slogans, or polarized along non-economic ideological dimensions such as religion or ethnic identity, and political promises are particularly lacking in credibility or prone to clientelism, it is precisely the broad social services that are most likely to suffer.

We point in the next section to pervasive failures of social service provision and argue that low demand for social services on the part of the poor is an unlikely explanation for these failures. A few simple theoretical illustrations then serve to identify the different factors that interfere with the ability of voters to hold politicians accountable for the quantity and quality of social services. The impact, particularly on social service provision, of each of these imperfections in political markets-information constraints, social polarization, and problems of political credibility-is then assessed.

The latter part of the paper demonstrates how the political market imperfections on which we focus help explain one of the more striking contrasts in government policymaking, the famous cases of the states of Uttar Pradesh and Kerala in India. We argue that the lack of voter information, greater social polarization and the non-credibility of political party platforms in the former state explains its failed social services relative to the well-performing 
services of Kerala. We conclude by exploring some implications of this political economy analysis for policy initiatives to improve the allocation of public resources. ${ }^{2}$

\section{Politics and Social Services}

The electoral market imperfections that we explore below help to explain a wellknown distortion in public spending, in rich and poor democracies: the preference of governments to spend on targeted programs, such as government jobs or infrastructure investment, rather than on improvements in broad social services. Feyzioglu, Swaroop, and Zhu (1998) find that when foreign aid is targeted at education, it is more likely to be offset by reductions in own-government financing of education. When aid is used to support public infrastructure investment (transportation and communications), however, the opposite is true: governments are likely to maintain their own fiscal effort in the provision of these goods. Foster and Rosenzweig (2001) and Pande (2003) have shown that when disadvantaged groups in India_- the landless poor and scheduled castes (respectively) — were newly able to elect their own representatives, more government resources flowed towards these disadvantaged groups. However, these increased flows largely took the form of increased access to government jobs and targeted welfare transfers. Enhanced political rights did not translate into improved education or access to other broad-based social services, though the resource cost of such improvements, relative to likely welfare gains, could have been much smaller. ${ }^{3}$

The preference of politicians for "pork barrel" or targetable spending is not the exclusive province of developing countries, and is widely documented in the United States (see, for example, Mayhew 1974). The problem for development is that many governments have exaggerated preferences for targeted expenditures at the expense of untargeted health

\footnotetext{
2 Our focus on fundamental characteristics of electoral competition is complementary to another literature (reviewed by Persson and Tabellini 2002) looking at the impact of electoral and political institutions on government decisionmaking. This literature begins with assumptions about the extent of voter information, their ideological predilections and the credibility of electoral promises and identifies the incentive effects of the rules of electoral competition and political decisionmaking. It shows that whether countries exhibit presidential or parliamentary regimes or employ majoritarian or proportional electoral rules, for example, have significant effects on spending. Presidential regimes and majoritarian electoral systems spend less in total or less on public goods. The impact of institutions should depend on the environment in which elections are conducted. In fact, preliminary work suggests that the magnitude of the institutional results varies significantly depending on the underlying electoral characteristics of countries that are the focus here. For example, in poorer or younger democracies, where voters are less likely to be informed and political competitors are less likely to be credible, the difference in government spending between presidential and parliamentary systems is less than half what it is in richer or older democracies. The analysis and review in this paper are therefore a logical first step in a full and comprehensive analysis of the political economy of government expenditures and the poor.

3 In their review of research on public spending and the poor, Van de Walle and Nead (1995) find that resources spent on basic health and education services ("broadly" targeted fiscal policies) have higher payoffs for the poor than finely targeted food subsidies or other redistribution schemes, in part because of the administrative costs and behavioral consequences of the targeted schemes.
} 
and education services that would more heavily benefit poorer landowners and landless laborers. For example, the bulk of expenditures in health and education typically flow to the salaries of teachers and health workers, yet rampant absenteeism and shirking by these service providers means that no services are effectively provided in many cases. That is, governments use these resources to provide (targetable) jobs rather than (less targetable) high quality services. ${ }^{4}$ Service delivery falls far below the levels that even poorer countries can afford, suggesting that the tradeoffs between targeted and non-targeted public expenditures are much steeper in these countries than in developed countries.

This evidence underscores a general point. Although the allocation of public expenditures away from the poor is often framed as a problem of "capture" by the "rich" of the levers of government policymaking, difficult allocation problems persist even when government expenditure programs are "pro-poor." Such programs frequently take the form of targeted (and often unsustainable) redistribution programs, such as free food and temporary employment in public works, even when other, cheaper and broad-based programs to improve basic health and education services would have a bigger impact on welfare.

In many cases, of course, the problem is not only that the poor receive inefficient targeted transfers rather than more efficient public goods, but that apparently broad-based programs benefit mainly special interests or the rich. Bates (1981) has shown for Africa that agricultural subsidies, such as price protection and subsidized electricity, disproportionately benefit middle and large farmers, who grow the protected crops and are more likely to engage in capital-intensive, power-driven private irrigation. India provides a wealth of examples, ranging from power subsidies to fertilizer subsidies, exhibiting the same characteristics. Once again, such biases are well-known in all democracies but are particularly extreme in many developing countries.

Understanding the variation in political market imperfections across countries that give rise to these exaggerated preferences is the goal of this paper. In particular, the paper asks: under what conditions can voters provide stronger incentives for politicians and service providers to provide high quality public services to all rather than targeted transfers, particularly targeted to rich special interests?

Although the analysis here focuses on the supply side - the incentives of political actors to provide public services — one might naturally be concerned that failures of social service provision in some countries are rooted in the demand side. Voters in poor countries

4 In India, recurrent expenditures on primary education accounts for 98 percent of total government expenditure on primary education; salaries account for 96 percent of recurrent expenditures, and teachers' salaries account for 97 percent of all salaries in education spending (Tilak 1993, p. 60). Yet, field investigations in rural areas of Indian states, particularly in the north, reveal that teacher absenteeism is endemic, with almost two-thirds of the teachers employed in the sample schools absent at the time of the investigators' unannounced visits (Drèze and Gazdar 1996; Weiner 1991; Prasad 1987). 
may simply not value health or education provision by the government. Scheduled caste members and the landless poor may similarly be unaware of the importance of education or, aware of the importance of education, but nevertheless prefer that their politicians provide other services.

Ignorance of the value of education seems not to be a sustainable thesis. A common finding of village studies and household surveys in India is that education is widely perceived by members of disadvantaged groups as the most promising chance for a better life for their children (Drèze and Sen 1995). Farmers, landless laborers, and scheduled caste members therefore know the importance of education for their children.

A thought experiment also makes clear that demand side considerations alone cannot explain why, even if fully informed about the value of education, the landless poor might still prefer targeted jobs. Suppose that a village must choose between demanding a single job for some, randomly chosen individual in the village, or the presence of a teacher from outside the village. Suppose the village has thirty families and that the teacher would instruct one child from each family. Further, assume that literacy raises the present value of each child's lifetime income by 30 percent, that literacy takes five years of education to achieve, and that the present value of each child's income, absent education, would be the same on average as that of the average wage earner in any of their families. Then the total value to all 30 families from having the teacher (assuming the teacher is guaranteed to stay for five years) would be $0.3 * 30 *$ (the present value of the average wage earner's lifetime income).

To match this wealth effect, and even assuming that the job offered in lieu of a teacher was guaranteed for the life of the recipient rather than for only five years, the job would still have to pay ten times the average wage to make the expected value of the job to the village the same as the expected value of the teacher. The demand for education would therefore have to be extraordinarily low, for example because returns to education are low, or discount rates are high, or severe credit market constraints block access to complementary inputs (books, foregone child labor), to explain the apparent preference of the poor in many developing countries for jobs and subsidies over schools and clinics. However, because we observe the poor making large sacrifices to educate their children-for example, in private institutions - despite imperfect credit markets and discount rates that are not particularly low, it makes sense to look beyond demand-side issues in asking why voters in some countries do not pressure politicians to provide high quality education.

\section{When Does Political Competition Lead to the Optimal Provision of Public Goods?}

A simple illustration indicates the stringency of the conditions under which elected officials always provide the socially optimal level of public goods. By implication, the example makes clear how imperfections in political markets can undermine the incentives of 
political decisionmakers to provide optimal government services to citizens. In this "benchmark" society, all political promises are credible, politicians cannot make targeted transfers (transfers to some voters but not others), voters are identical, and voters can observe at no cost the contribution that politicians make to their welfare. Under these conditions, the public good preferences of voters always translate into actual government policy.

To see this, assume there are $N$ identical voters, whose individual welfare $W$ is given by $c+V(g)$, where $g$ is the amount spent on public goods, $c$ is consumption and $V(g)$ is the utility from public spending; $c=y(1-\tau)$, or income net of a uniform tax $\tau$, and $g=\tau N y$. The welfare of the average or median voter (the same in this case, since all voters are identical) is therefore maximized by public good provision $g^{*}$ such that $V_{\mathrm{g}}\left(g^{*}\right)=-1 / \mathrm{Ny}^{5}{ }^{5}$ This is precisely the level of public good provision that maximizes total social welfare (taken to be the sum of the welfare of all $N$ voters). Any candidate who deviates from the policy promise $g^{*}$ and $\tau=$ $g^{*} / N_{y}$ is defeated by any candidate who offers this optimal policy package, since all voters prefer $g^{*}$ to any other $g$.

The example is unrealistic for many reasons. However, each of the deviations from reality illuminates a political obstacle to the broad-based delivery of quality social services by government. One key assumption in the benchmark model is that voters can costlessly observe the contribution of politicians to policy changes and the connection between government policy and their own welfare. Politicians therefore always get credit or blame for the actions they take or fail to take on behalf of voters. Imperfect voter information makes it difficult for voters to assign credit or blame, and therefore increases political incentives and scope for rent-seeking. Persson and Tabellini (2000) argue that the larger the density of citizens who are uninformed and therefore vote randomly (that is, with complete disregard for policy promises and outcomes), the greater is political rent extraction in equilibrium. In the limit, if voters are utterly ignorant about politician responsibility for government policy or about the contribution of policy to their own welfare, the results from the benchmark model entirely reverse and no public goods at all are provided.

Voters are also assumed to be identical in the benchmark model. Obviously, though, voters differ on a host of margins, including income, ideology, religious belief, language, the value they attach to different public goods, occupation and location. All of these affect their preferences for government policies and public goods, and make the coordination problem of setting a threshold for re-election of candidates more difficult. If voters have strong preferences for or against specific candidates or parties, independent of the policy choices of these parties, social service provision can suffer significantly. It is easy to show the potentially devastating impact of ideological preferences on outcomes in the ideal world.

\footnotetext{
5 Rewrite welfare in terms of $g$ and maximize with respect to $g$.
} 
Imagine that there are only two political parties competing for votes. Some voters derive utility from the election of party $A$ and disutility from the election of party $B$, and the remaining voters derive utility from party $A$ and disutility from party $B$. For simplicity, voters who prefer party $A$ are identical in their preference for party $A$, as are the voters who prefer party $B$. Further, the disutility that voters get when their non-preferred party is elected is exactly equal to the utility they get if their preferred party is elected, and the amounts of utility and disutility for each group of voters are the same. That is, for all voters, the utility they get if their preferred party is elected is $\varepsilon$, and the disutility they get if their non-preferred party is elected is $-\varepsilon$. As before, politicians representing each party make promises regarding public goods and elections are held. When ideological polarization is severe enough, however, politician promises regarding public goods are irrelevant.

Consider, for example, a situation in which half of all voters prefer party $A$ and half prefer party $B$. If party $A$ is elected, voters who prefer party $A$ receive $W_{A}=c+V\left(g_{A}\right)+\varepsilon$ and voters who prefer party $B$ receive $W_{B}=c+V\left(g_{A}\right)-\varepsilon$, where $g_{A}$ is the level of public goods promised by party $A$. Conversely, if party $B$ is elected, welfare outcomes for each group of voters are given by $W_{A}=c+V\left(g_{B}\right)-\varepsilon$ and voters who prefer party $B$ receive $W_{B}=c+V\left(g_{B}\right)+\varepsilon$. If ideological preferences are zero, $\varepsilon=0$, the two parties both promise $g^{*}$. However, as $\varepsilon$ grows, voters become more willing to vote for their preferred party even if that party promises fewer public goods than the non-preferred party. If social polarization is sufficiently high and $\varepsilon$ sufficiently large so that $V\left(g^{*}\right)+y\left(1-g^{*} / y\right)-\varepsilon<V(g)+y(1-g / y)+\varepsilon$ for all $g$, or $V\left(g^{*}\right)-V(g)+g-g^{*}<2 \varepsilon$, there is nothing that the non-preferred party can promise prior to the election that will convince the supporters of the other party to switch their allegiance. The welfare that the supporters of the other party receive from electing their own party, even if their own party provides no public goods at all, is greater than the welfare that they receive if the other party is elected and provides the optimal level of public goods. 6

The third key assumption of policymaking in the ideal world is that pre-electoral promises are binding on the election winners. This is clearly counterfactual: electoral promises are not legally enforceable anywhere. Instead, the credibility of campaign promises depends on the reputation of either the individual candidate making the promises or of the political party to which candidates belong. In many cases_-such as young democraciesreputations are weak or have been established for only a limited number of issues. Individual politicians or parties may be well-known and believable as freedom fighters or as defenders of a religious faith, but have no reputation with regard to education, health services or economic policy.

When electoral promises are not credible, challengers are in a much weaker position with respect to incumbents. Even if voters observe bad incumbent performance, challengers are hard-pressed to convince voters that they would do better, since none of their claims is

6 Governments cannot extract rents in the ideal world. If they could, they would be easier to extract in a polarized world, where voters prefer parties regardless of their policy performance or rent-seeking. 
credible. Incumbents are therefore strengthened and thereby entirely or almost entirely freed from the need to respond to electoral pressures. This is a pervasive problem in young democracies, which has been extensively analyzed.

If, as in Robinson and Verdier (2002), no promises are credible, politicians have no incentive at all to pursue the public interest except to the extent that it directly improves their own private welfare. For example, incumbents might approve public expenditures on roads as long as the roads pass by their privately-owned factories. In this limiting case, noncredible politicians set the tax rate $\tau$ to maximize the rents that they can extract from the economy during their expected time in office and provide no public goods whatsoever. Elections are almost meaningless in this context. Ferejohn (1986), however, shows that elections can serve the purpose of removing from power an incumbent that has performed poorly, if voters can implicitly coordinate to establish some threshold of performance that the incumbents must meet if they are to be re-elected. Such a threshold provides only weak voter control over incumbents, since incumbents always have the opportunity of "looting" taking all of the rents possible in a given period and foregoing any chance for re-election.

Persson and Tabellini (Chapter 8, 2000) refine the Ferejohn model, introducing the possibility that politicians can make targeted transfers as well as provide public goods. They show that if, for example, politicians need to attract the votes of 51 percent of the electorate in order to be elected, incumbents provide public goods as if only 51 percent of voters benefited from them rather than all voters. This implies significant under-provision of the public good. An attempt by any majority of voters to demand a higher level of public goods would be undercut, because the incumbent could always offer targeted transfers to a few voters that offer greater welfare than the extra public good but are cheaper for the incumbent to provide. However, since all voters would like to receive such transfers, they bid them down to zero.

The Ferejohn-style model may be somewhat more realistic, despite its reliance on an apparently strong assumption of voter coordination. In countries with weak and noncredible political parties, it is common for voters to reject incumbents after particularly bad performance, but to be unable to demand better performance from successors. Keefer (2000b) introduces yet another variant of the credibility argument that may be still more realistic. He argues that politicians in every country can make credible promises to some voters, but that in many countries those voters have personal ties to the candidate-for example, the ties described by the "patron-client" relationships that a large literature has identified with the politics of developing countries. Such "partial" credibility also undermines political incentives to provide public goods.

The benchmark model assumes that governments can only provide public goods. However, in every country the ability to make targeted transfers is a key weapon in the political arsenal and almost always directly conflicts with the goal of providing efficient public services to those who most benefit from them. Benefits are targeted according to 
political calculations that need not and often do not coincide with technocratic notions of targeting, which emphasize targeting according to other criteria, such as need. Political and program targeting criteria need not and usually do not coincide, undermining adequate social delivery.

To see the implications of political targeting, one can assume $N$ identical voters, as before, and allow individual voter welfare $W$ to be given by $c+V(g)+m_{i}$, where $m_{i}$ is a transfer from the government to voter $i$. As before, $c$ is $y(1-\tau)$, but $\tau N y=g+\sum m_{i}$. For even the slightest deadweight loss from taxation, $m$ should be zero since the utility gain of transfers to any voter is offset by an equal utility loss borne by other voters. However, there are many possible realistic scenarios under which politicians would prefer only to provide $m$. If voters can only verify promises related to the direct provision of targeted goods (e.g., a job), but not of broad public goods (e.g., efforts to improve school quality), politicians have an incentive to provide only transfers to voters. ${ }^{7}$ If most voters are ideologically polarized, but some are not, politicians would compete by making promises only to the ideologically uncommitted. If this group were small enough, its members would prefer all tax revenue to be used to provide them with targeted transfers than with public goods that would benefit all citizens. $^{8}$

Regardless of which model is more appropriate, the examples drive home a point that reappears throughout the discussion in this paper. Any set of institutions that can sustainably guarantee accountable and responsive government includes competitive elections, but elections by themselves are far from a sufficient condition for good governance given imperfections in the market for political competition. Each of these imperfections - information asymmetries, social polarization, and non-credibility of political promises - is explored in greater detail in the sections that follow. In every case, substantial evidence suggests that these imperfections are important sources of distortion in political markets and that reform efforts designed to improve the access of the poor to quality social services need to address them explicitly in order to be successful.

\section{The Impact of Imperfect Information on the Provision of Social Services to the Poor}

${ }^{7}$ In the absence of additional structure, there is no equilibrium policy outcome in the simple model of targeted transfers. There is no offer of transfers and public goods that is invulnerable to defeat by some other offer. Transfers to each voter each constitute a different policy dimension and Plott (1967) shows that majority rule with a multi-dimensional policy space is unlikely. Many of the political institutions discussed in this paper solve this problem. For example, most political systems grant agenda setting authority to some elected officials but not to others. Those officials can make take-it-or-leave-it offers to other policymakers, thus offering an institutional solution to the problem of policy instability introduced by politically targeted transfers. Such institutional innovations tend to give rise to their own distortions.

8 That is, for any amount of tax revenue, a small group of $k$ swing voters would prefer transfers to public good provision as long as $V_{\mathrm{g}}<1 / k$, where $1 / k$ is the marginal utility gain for members of this group of an additional unit of transfers to them. 
Incomplete information is at the heart of most theories of the breakdown of political markets. It is therefore worth recalling first that the presence of well-informed voters is not always necessary to persuade politicians to follow policies that benefit the society. Detailed behavioral studies in the United States have shown that voters adopt simple voting criteria based on very limited information about politics and public policies (various articles in Ferejohn and Kuklinski 1990). Motivated by these findings, Fiorina and Shepsle (1990) and Chappell and Keech (1990) argue that citizens can employ voting rules requiring very little information and still motivate politicians to pursue policies in their interest. Ferejohn (1990, pp 8-9) paraphrases this process as follows: "find a way to get the electorate to commit itself to act as though it is a simple principal with a one-dimensional set of rewards. In this way, incumbents will be prevented from taking advantage of the conflicting interests in the electorate". Hence, if the electorate in aggregate is able to coordinate on a common set of issues then politicians would have incentives to pursue policies as defined by those issues. Policy choices are therefore determined by those issues that voters are informed about and choose to coordinate their voting decisions upon.

Fiorina (1990) emphasizes that most of the information people use to make voting decisions is essentially "free", in that it comes with the ordinary performance of social and economic roles. However, the poor have less access to "free" or nearly free information and, in any case, such information is less widely available in developing countries. Newspapers are either of lower quality, or few in number, or available only to the minority of literate voters, while radio and television stations are often state-controlled. In addition, the content of "free" information can vary widely over the electorate depending on the differentiation of occupations in the economy and the variability of social settings. Citizens then specialize in information about some things rather than others, inhibiting coordination (Ferejohn 1990; Iyengar 1990; Ottati and Wyer 1990). In countries where limited media reach and difficult transportation and communications systems divide the electorate, this problem is exacerbated. It is a small leap to the conclusion that the information base of poor, rural citizens of developing countries is therefore skewed in a way that detracts from their ability to hold elected officials accountable for the quality of public services.

There is very little systematic empirical evidence on the nature of information available to poor voters and used by them to evaluate their political representatives. Some econometric and some anecdotal evidence suggests that poor voters are more susceptible to reward (or punish) politicians for exogenous changes that affect their welfare, for short-lived policies or campaign promises just before elections, or for targeted policies where the actions of political agents are immediately visible. All of these information problems reduce political incentives to effectively provide broad social services.

Poor voters are less able to disentangle the contribution that elected officials have made to their welfare from the contribution made by exogenous circumstances, such as due to forces of "nature". In India, for example, it appears that state governments tend to lose 
elections in years of poor rainfall. But this effect of voters making errors in their assessment of politician performance when confronted by noisy environmental signals is also evident in developed countries. Wolfers (2002) finds that voters in oil-producing states in the United States tend to re-elect incumbent governors during global oil price rises and vote them out of office when the oil price drops. ${ }^{9}$

Poor voters are more likely to place excessive weight on the recent or the immediately visible, thereby creating perverse political incentives to boost spending and to divert funds to short-term visible objectives shortly before elections. Although evidence for electoral budget cycles in developed countries is at best ambiguous, Shi and Svensson (2002), Block (2002), and Schuknecht (2000) find large electoral cycles in monetary and fiscal instruments in developing countries. Shi and Svensson (2002) establish a direct link between electoral budget cycles and limited information available to voters, showing that some of the difference in the size of political budget cycles across countries is due to variation in access to free media-the greater is access, the smaller are the observed budget cycles.

This emphasis on the recent and visible is a particular problem for investments in some public services for which the measurable outcomes of policy change may not emerge for several years after the policy action has been taken, or where outcomes are noisy signals of politician effort and ability. The effects of education reforms, for example, are typically difficult to verify until a cohort of students has been exposed to them for a sufficient period of time. Even then, it is difficult to credit politicians with the improvement in performance of a school or a clinic, as outcomes depend critically on the day-to-day performance of other agents such as teachers or doctors, and impact of political actions, such as institutional reforms that improve provider accountability, are more opaque. In contrast, policy actions such as building a highway, or building a school, are both more visible and easier to attribute to political agents. ${ }^{10}$ Although there is little evidence of large scale swings in spending around election times in an older democracy in the developing world, India, Khemani (2003) does find that the composition of spending and revenues changes, possibly to target special interest groups in exchange for campaign support. As the time of elections draws near, state governments in India increase expenditures on public investment projects and away from more broad-based categories of spending on public services, and provide targeted tax breaks to narrow groups of producers possibly in exchange for campaign finance.

9 Filtering out performance from noisy signals in outcomes is a pervasive issue in principal-agent problems, and not somehow restricted to or especially intractable for the citizen-politician agency problem. Bertrand and Mullainathan (2001, p. 1) find, for example, that CEO pay "responds about as much to a lucky dollar as to a general [earned] dollar".

10 Mani and Mukand (2002) show that if elections serve the purpose of voters choosing amongst candidates to select the most competent one, then resource allocation will be biased against those public goods whose outcomes are more noisy and harder to use to assess politician ability, as politicians will have the incentive to provide other goods that are better signals of high ability. 
Rather than being influenced by independent evaluations of the performance records of competing candidates, uninformed voters' decisions are swayed by political campaigns and advertisements, thereby creating a role for special interests to purchase narrowly targeted policies by providing campaign finance (Baron 1994; Grossman and Helpman 1996). Special interests could be single firms, groups of manufacturers, farmers, public sector employees, or subsidized retail store owners. ${ }^{11}$ They need not be rich, but they are, by definition, informed. To the extent that the poor are disproportionately uninformed, therefore, the organized poor are likely to be under-represented as special interests. Similarly, to the extent that voters in developing countries are less informed, broad public policies are likely to be distorted in favor of special interests.

One policy consequence is simply that imperfectly informed voters are less wellserved by government. The flip side of this argument is that governments accountable only to uninformed voters can be more vigorous in the pursuit of their own private interests. Because uninformed voters cannot easily identify the effect of rent-seeking on their welfare, politicians have greater scope to extract rents (Persson and Tabellini 2000).

There is recently emerging evidence that when voters are informed about particular policies they are able to extract greater resources and better performance from political agents. Strömberg (2001) finds that between 1933 and 1935 in the United States, federal assistance to low-income households was greater in those counties where more households had radios and were thus more likely to be informed about government policies and programs. The spread of the radio particularly improved information access for rural voters, who were previously disadvantaged relative to urban voters (since the latter already had access to alternative sources of information such as newspapers, while radio waves made it easier to deliver information to remote areas). It accounted for as much as 20 percent greater allocation of social assistance funds to a rural county as compared to an identical urban county. Besley and Burgess (2003) find that state governments in India are more responsive to declines in food production and crop flood damage via public food distribution and calamity relief expenditure when newspaper circulation, particularly in local languages, is greater.

While telling, this evidence does not inform the broader question of whether policy is more socially beneficial when voters are more informed. In particular, it is not clear that informed voters were more "deserving" of transfers, nor can one draw the conclusion from this evidence that more informed voters heighten government incentives to provide public goods. It could, for example, be the case that the mass media better enabled politicians to take credit for targeted payoffs to particular constituencies, leading them to reduce expenditures on public goods or on broad-based social programs. The evidence provided by both Strömberg (2001) and Besley and Burgess (2003) is based on information about

11 Alderman (1988) describes protests in Pakistan by retailers of government subsidized wheat and flour when their livelihood was placed at risk because of amendments in the subsidies program. 
targeted transfers, which is perhaps an area of public policy that the poor are more informed about given that they are the intended beneficiaries of redistributive programs. Yet, information distortions in favor of targeted programs may further blunt political incentives to provide broad social services.

The negative impact on the poor of information distortions in political markets therefore arises on two counts. The poor are less likely to be informed, with less access to universal sources of information, such as newspapers and radio, as well as to accurate informal information networks, and therefore less likely to receive government resources. At the same time, the poor rely most on the publicly provided social services for which information problems are the most acute, and most likely to lead to such services being underprovided. Health and education are transactions-intensive and depend critically on dayto-day provider behavior; outcomes are sensitive to provider discretion as well as to the overall policy parameters of the sector. Reforms affecting teacher performance in the classroom or rates of infection in hospitals are not easily observed by voters. For example, voters can easily verify that politicians have complied with a promise to bring a teacher to their school. They can less easily verify that the teacher is good, or that the teacher will remain for a sufficient period of time to deliver high benefits to the village. If politicians cannot take credit for their efforts to improve teacher quality, they provide and voters expect low-quality teachers.

The quality problem is exacerbated when the political rewards are high from targeting particular providers for contracts or jobs, including teaching jobs. Since voters do not give the politician credit for providing them with high quality teachers, anyway (since they cannot observe quality), politicians have an incentive to use their clout to fill teaching jobs with the nieces and nephews of constituents, regardless of their professional qualifications. In fact, the lower the quality of the service provider, the higher the rents that providers receive and the greater their debt to the politicians. Gazdar (2000) and the World Bank $(1998,2001)$ make it clear that non-professional qualifications are key factors in the placement of teachers in Pakistan. Similar reports from the Dominican Republic suggest that posting of teachers is highly discretionary and not clearly related to educational concerns (Keefer 2002a).

Information problems may thus lead poor voters to give greater credit to politicians for initiating public works projects (including school construction), providing direct subsidies for essential commodities, and increasing employment in the public sector (including hiring teachers and doctors), than for allocating resources and reform efforts towards improving actual quality of education and health services, such as ensuring teacher and doctor attendance, or that school and clinic buildings are properly equipped. 


\section{Social Polarization and Provision of Services to the Poor}

Studies of electoral politics in India show that identity characteristics along ethnic, linguistic and religious lines dominate political behavior (Weiner and Field 1974). Similarly, in Nigeria, social cleavages along the lines of religion and ethnicity play a prominent role in determining political behavior. In socially polarized and/or ethnically fragmented societies, voters therefore tend to vote for those candidates they most closely identify with, irrespective of public performance and policy records; political competition between parties thus also concentrates on identity issues, and candidates are nominated from constituencies largely on the basis of demographic calculations of ethnicity and religion. Like uninformed voters, polarized voters are therefore also less able to hold politicians accountable for their performance in office. Public good provision should suffer most under these conditions, since politicians in polarized societies rarely internalize the society-wide costs and benefits of their policy decisions.

These voting patterns are not the same as "ideological" voting in the United States or Western Europe. Surveys of voting behavior in the United States in the 1950s and 1960s (Campbell and others 1966) show that an overwhelming determinant of voting behavior is the ideological identification of voters with political parties. In this case, though, ideology has significant policy roots-in citizen identification with the perceived position of political parties on a wide range of social and economic issues.

Why the difference between India and Nigeria, on the one hand, and the United States on the other? There are two possibilities. The implicit argument in much of the literature, is simply that members of the same ethnic, religious or social group value each others' welfare much more than the welfare of members from other groups. As a consequence, the utility they derive from providing public goods to all is lower than it otherwise would be.

A second possible explanation receives more attention in the next section of the paper: where political competitors are generally not credible, voters rely on personal connections to competitors to establish which are credible and likely to provide them benefits once in office. In the United States, parties have established credible positions on certain issues, which together comprise a package that attracts particular voters who then appear to be "ideologically" committed to the party-when in fact, they are committed to the policy positions with which those parties are credibly associated. In India and Nigeria, though, the problem is the reverse. Voters only believe promises from political candidates within their own ethnic or religious groups; those promises are therefore, necessarily, narrow and targeted to members of the respective ethnic group. Political promises for broad-based public services that cut across social groups are not credible.

In a cross-country setting, Easterly and Levine (1997) find that ethnic diversity is negatively correlated with the provision of public goods such as the percentage of roads that 
are paved, efficiency of the electricity network, and years of schooling of the population. For cities in the United States, Alesina, Baqir and Easterly (1999) show that shares of public spending on productive public goods-education, roads, sewers, and trash pick-up—are inversely related to the city's ethnic fragmentation. Miguel (2001) concludes that higher levels of local ethnic diversity in Kenya are associated with sharply lower contributions to primary school funding and worse school facilities. These results are consistent with either theory of social polarization. Animus across ethnic groups explain these outcomes directly. However, if individual politicians can only make credible promises to members of their own ethnic groups, it makes little sense for them to provide public goods that benefit all ethnic groups. The credibility theory therefore also explains these findings.

The effects of identity politics are much more dramatic when minority identities lack political power. They then suffer in public policy decisions decided by the majority. In India, Betancourt and Gleason (2000) find that districts with a higher proportion of traditionally disadvantaged groups with respect to caste and religion- the scheduled castes and Muslims - have lower public inputs in health and education. Similarly, Banerjee and Somanathan (2001) find that districts with a higher share of scheduled tribes in population receive significantly fewer "desirable" public goods. They also find some evidence that links the relationship between ethnic heterogeneity and public good delivery to underlying political incentives - districts that are ethnically fragmented are also likely to be politically fragmented, in that elections in these districts are characterized by a larger number of contestants and a smaller vote share for the winning party.

There is also substantial anthropological and anecdotal evidence in India that disadvantaged groups are systematically excluded from using public goods within their own villages by social processes of discrimination. Micro-level case studies and survey evidence from India show that within-village inequality in education access and achievement is significant, with the privileged castes in the village enjoying near-universal adult literacy for several decades while literacy rates are still close to zero among disadvantaged castes in the same village (Drèze and Sen 1996).

The effects of increasing the political power of minority groups provides some indication that both problems of inter-group hostility and of credible commitments in political competition undermine public policy in polarized countries. India, for example, instituted political reservations for scheduled castes and tribes in the national and state legislative assemblies. Pande (2003) finds that mandated reservations in state legislatures resulted in increased public sector job quotas for scheduled castes in the public sector, but significantly lower resources allocated to education. The antagonism of the majority towards the scheduled castes and tribes explains why the greater political influence of the latter led to a change in benefits. However, the fact that politicians find it difficult to make credible promises about public goods across ethnic and caste groups explains why public good provision-education-declined. 
Because the newly emergent representatives of the disadvantaged groups could make credible appeals only to their ethnic groups, they favored targeted rather than broad public goods, even when the benefits to their groups would have been higher, per rupee expended, from the latter. Mandated reservations may in fact improve the equity of targeted transfer programs, but worsen overall social service delivery by strengthening clientelist relations and reducing incentives of political competitors to invest in broad policy reputations across the electorate.

Unfortunately, though parties could gain by attempting to build such reputations, there are also strong political incentives in the opposite direction. As Glaeser and Shleifer (2002) have shown in the case of the city of Boston, as the experience of Zimbabwe makes self-evident, and has been the case throughout history, politicians can often gain political advantage by fanning ethnic divisions. In the limit, as in Boston or Zimbabwe, electoral advantage is cemented by simply pushing the out-of-power ethnic group out of the jurisdiction.

\section{Credibility and the Provision of Social Services}

As the previous sections have foreshadowed, credibility influences the provision of social services in two important ways. First, credibility sharpens the effects of competitive elections on politician incentives. When campaign promises are not credible-when it costs election winners little to abandon them-electoral competition has relatively modest effects on service provision. Public goods are likely to be under-provided in less credible political environments. One aspect of this has already been discussed: when the quality of social services is difficult for voters to observe, voters cannot easily verify whether quality public goods have been provided or not. Absent this verification, politicians have an incentive to under-provide relative to what they have promised.

The notion of political credibility and its implications for public policies has only just begun to be explored, and as yet there is little available in terms of a systematic and rigorous development of the determinants of credibility. Credibility is conceptually close to reputation, and reputation depends on social/legal institutions available to enforce promises, or can be developed over repeated interactions. Old democracies may develop political credibility through recurrent elections over a period of time. Credibility of political promises may therefore be a particular problem in developing countries that are newly democratizing, and hence have not developed political reputations, or because overall social, economic, and legal institutions are not conducive to establishing reputations.

Reputation can also develop for the "wrong" policies when there is uncertainty about the most effective instruments to achieve particular public objectives, and the history of political competition may lead to a "bad" equilibrium where only certain promises, for inefficient policies, are credible. For example, new democracies established in poor, 
agricultural economies have historically adopted poverty reduction strategies focusing on subsidies for consumption and agricultural production, at the expense of broad public services that may perhaps have higher returns in terms of poverty impact and economic growth. But once political reputations are established for particular policies, even if these policies are sub-optimal they will receive greater public resources than if all political promises were credible.

Second, credibility affects the types of public goods that politicians offer. In countries where voters believe political leaders are less secure in their positions, they place less value on promises by political competitors to improve the quality of education, which are of no value unless they are carried out for a substantial period of time, and more value on promises whose benefits are immediately realized. These two factors are discussed in greater detail in the sections that follow.

\section{The Credibility of Political Promises and the Impact of Clientelism on Social Service Delivery}

The earlier discussion emphasizes that when pre-electoral promises are not credible, elections become less effective devices for holding politicians accountable. Under two scenarios of non-credibility reviewed earlier, voters can either coordinate on ex post performance standards, as in Ferejohn (1986) and Persson and Tabellini (2000), turning out incumbents that fail to meet them and mitigating the credibility problem, or they cannot, as in Robinson and Verdier (2002), rendering elections useless. In these models, public goods are underprovided, targeted transfers are not provided at all, and rent-seeking is high. We know, however, that politicians in developing countries are deeply concerned about their ability to deliver targeted transfers to constituents. At the same time, we know that political party development and other indicators of credibility in political systems are weak in many of these countries. If politicians are credible, but only to individual voters with whom they have built up a personal reputation, both rent-seeking and targeted transfers are high, as we observe. Keefer (2002b) argues that this "partial" credibility explains the policy outcomes we observe in less credible democracies, including the phenomenon of vote buying.

In such countries, the foundation of a politician's credibility is not based on the politician's policy record or history of policy stances, bolstered perhaps by the policy record of the political party to which the politician belongs. Some voters believe some politicians who have, for example, shown themselves to be reliable sources of personal assistance. These might be locally influential people who have helped families with loans or jobs or assistance with legal or bureaucratic difficulties. In the absence of well-developed political parties or national party leaders who are more broadly credible to voters, the promises of such influential people are all that voters can rely on in making electoral choices.

The credibility of pre-electoral promises only to clients has precise implications for policy: the greater the emphasis on building credibility through personalized exchange, the 
greater the focus of government spending on items targeted to specific individuals (clients) and, ultimately, the less spent on public goods. Promises of buildings and government jobs become the currency of political competition at the expense of universal access to high quality education and health care. The former can be targeted to individuals and small groups of voters (clients) and therefore are clearly seen as evidence of political patrons fulfilling their promises to clients. Universal access is by definition not easily targeted. Improvements in quality are also difficult to target, to the extent that they are difficult for voters to attribute to politicians. ${ }^{12}$

Evidence supports the notion that clientelist governments have a stronger than average preference for targeted infrastructure provision and tend to be more corrupt than average. For example, Keefer (2002b) argues that the age of democracy is one important characteristic of countries that influences whether political competitors are non-credible or clientelist or not. Because they are young, with fewer years and elections with which to have built up policy reputations, political competitors are less likely to be able to make credible promises to all voters and are more likely to rely on clientelist promises (targeted promises to specific individuals or groups to whom they can make credible promises for various reasons, including past dealings with them). In fact, targeted spending-public investment—is higher in young democracies than in old. Moreover, as young democracies age and the number of clients rises, targeted spending in the form of public investment increases. Keefer (2002b) also reports that corruption falls as democracies age, and that corruption is significantly higher in young than in established democracies.

These results are relevant for social service delivery since social services are likely to be of lower quantity when public investment is high and of lower quality when corruption is high. Qualitative evidence from Pakistan supports this contention. Competitive elections were a regular feature of the political landscape of Pakistan during the 1990s, but credible promises by political parties or political leaders to voters were supported largely by clientelist relationships and related to targeted transfers rather than broad public policies. There is little evidence of political competition on the basis of broad policy promises, nor of distinctions among the major parties regarding their stances on broad policy issues. One would expect the provision of broad-based public goods in such an environment to be low and the provision of targeted goods to be emphasized. In fact, compared to countries with similar incomes per capita and demographic characteristics (age and proportion rural), access to potable water in Pakistan in 2000 was 25 percentage points higher than expected.

Investments in potable water, particularly in rural areas where they consist largely of welldrilling, are particularly easy to target and their benefits are immediately accessible and

12 Voters cannot distinguish whether the quality or attendance of teachers has improved because of their own pressure on the teacher, because the teachers themselves decided to do a better job, because of a generalized reform in teacher quality that is affecting all teachers and education beneficiaries, or because of the targeted intervention of a particular politician. 
observable. Primary school enrollment, though, was 20 percentage points less than one would have expected, controlling for the same variables (World Bank 2002). ${ }^{13}$

\section{Horizon Problems and Credibility}

A second credibility problem emerges when political competitors, whose term in office is expected to be short, make promises that are credible for as long as they are in office. This leaves them unable to credibly promise to implement projects that require a longer time period to bear fruit. This matters little if the promises concern jobs or public works projects, which, in principle, can be fulfilled with little delay after an election and whose benefits can be quickly realized and recognized by voters. However, shortened political horizons render other government services, such as education, considerably less useful.

Education must be received for a certain minimum period of time before recipients realize any benefits from them. This is particularly true in the early years: schooling yields few benefits until students achieve literacy and numeracy, but this may not occur before the fourth grade. Using data from Spain, Sanmartín (2001) finds generally low returns to education prior to $10^{\text {th }}$ grade, but a spike in returns to education upon completion of the fourth grade. Glewwe and Jacoby (1994), in examining the determinants of student achievement in Ghana, gave subjects a basic reading and mathematics test. Performance by those who had not advanced beyond grade school was so poor that they were excluded from the sample and the authors focused on middle school achievers only. To the extent that education also serves a signaling function, the horizon problem worsens: receipt of the credential generates a discrete jump in the returns of the previous years of schooling, but the credential can only be received after a certain number of years of schooling. ${ }^{14}$

The horizon problem can have a significant impact on voter decisionmaking. Recalling the earlier example of 30 families, each with a school age child. They can choose between a politician who promises to provide a job and a politician who promises to staff the empty school with a qualified teacher from outside of the 30 families. Prior to the election, they do not know which family will get the job, so the expected value to each family of the job is $1 / 30$ of the salary. If the teacher is certain to stay for five years, each child becomes numerate and literate, raising expected lifetime income. Otherwise, there is no

13 Another, complementary explanation taken up in just the next section is political instability. For decades Pakistan has been marked by considerable political instability. The tenure of incumbent leaders was frequently cut short (three times in the 1990s). This would also have generated a marked preference for the provision by government of goods that generate benefits immediately and would not be dependent on the decisions of future governments.

14 The magnitude of the signaling effect is contentious, particularly for primary and secondary education. Layard and Psacharopoulos (1974) strongly dispute it, but Hungerford and Solon (1987) claim to find convincing evidence of it. 
benefit to education. If politician promises are credible over five years, the voters prefer the teacher; otherwise, they do not.

Again, indirect evidence suggests political horizons affect government policies with long-term effects, like education. Clague and others (1996) consider the security of property rights, another outcome of state institutions that is sensitive to the horizons over which government actors can make credible promises. They make the argument that the older is a regime (the years a country is democratic or that an autocrat is in power), the longer is the horizon of the political decisionmakers. The evidence they present suggests that the security of property rights is higher in both older democracies and older dictatorships. Keefer and Knack (2002) find as well that productive public investment - the payoffs to which are largely in the future-fall when property rights are weak, while unproductive public investment-corruption and rent-seeking-rise. These results are suggestive, at least, that in the area of social service provision, particularly education is likely to suffer when the horizons over which government officials can make credible promises are short.

\section{The Dynamics of Political Competition and Provision of Social Services: Uttar Pradesh versus Kerala}

Some of the most striking contrasts in basic health and education outcomes exist between neighboring countries with comparable levels of economic development, and between regions within the same country-between Sri Lanka, Thailand, and the southern states of India on the one hand, and Pakistan, Bangladesh, and the northern states of India on the other. One such contrast, between the northern state of Uttar Pradesh (UP) and the southern state of Kerala in India, has been explored in depth by Drèze and Sen $(1995,1996)$. These two states exhibit almost identical levels of per capita income and poverty, but dramatically different outcomes in health and education. Drèze and Sen attribute these stark differences to the divergent nature of public action in these respective states. We reinterpret their example to emphasize the differences in political incentives of policy-makers across the two states to provide social services to all.

Table 1 (based on data presented in Drèze and Sen 1996) summarizes this contrast. Human development outcomes in Kerala are comparable to some of the richest nations of the world, while those in UP are similar to those in the poorest nations of the world, despite the two having very similar economies, levels of per capita income, and poverty. Figure 1 suggests that the difference in human development outcomes is due, at least in part, to the striking differences in real per capita public expenditures on health and education in the two states. Over four decades from the 1960s to the 1990s, average real per capita spending in each decade in Kerala has been more than double that in UP. 
Table 1. Contrasting Experience in Social Services

\begin{tabular}{|c|c|c|c|}
\hline & India & Uttar Pradesh (UP) & Kerala \\
\hline $\begin{array}{l}\text { Per capita income at current prices 1991-92 (in } \\
\text { Indian rupees) }\end{array}$ & 5,583 & 4,012 & 4,618 \\
\hline Poverty headcount ratio, $1987-88(\%)$ & 44.9 & 47.7 & 44 \\
\hline $\begin{array}{l}\text { Real (1992 Rs) per capita public spending on } \\
\text { education, 1985-92 }\end{array}$ & 228 & 147 & 309 \\
\hline $\begin{array}{l}\text { Real (1992 Rs) per capita public spending on health, } \\
\quad 1985-92\end{array}$ & 70 & 49 & 82 \\
\hline \multicolumn{4}{|l|}{ Literacy rate, age 7+, $1991(\%)$} \\
\hline Female & 39.3 & 25.3 & 86.2 \\
\hline Male & 64.1 & 55.7 & 93.6 \\
\hline \multicolumn{4}{|l|}{$\begin{array}{l}\text { Percentage of rural children aged } 12-14 \text { who have } \\
\text { never been enrolled in a school, } 1986-87\end{array}$} \\
\hline Female & 51 & 68 & 1.8 \\
\hline Male & 26 & 27 & 0.4 \\
\hline \multicolumn{4}{|l|}{$\begin{array}{l}\text { Proportion of persons aged } 6 \text { and above who have } \\
\text { completed primary education, } 1992-93\end{array}$} \\
\hline Female & 28.1 & 21.4 & 60.5 \\
\hline Male & 48.6 & 47.3 & 65.8 \\
\hline $\begin{array}{l}\text { Proportion of children aged } 12-23 \text { months who } \\
\text { have not received any vaccination, } 1992-93\end{array}$ & 30 & 43 & 11 \\
\hline $\begin{array}{l}\text { Proportion of recent births preceded by an } \\
\text { antenatal check-up, 1992-93 }\end{array}$ & 49 & 30 & 97 \\
\hline Infant mortality rate per 1000 live births, 1990-92 & 80 & 98 & 17 \\
\hline Proportion of villages with medical facilities, 1981 & 14 & 10 & 96 \\
\hline
\end{tabular}

Source: Drèze and Sen (1995, 1996); Public spending numbers from annual publications of the Reserve Bank of India Bulletin on state finances in India; India-wide numbers on public spending only for 15 major states.

Figure 1. Public Spending on Health \& Education (Per Capita 1992 Rs)

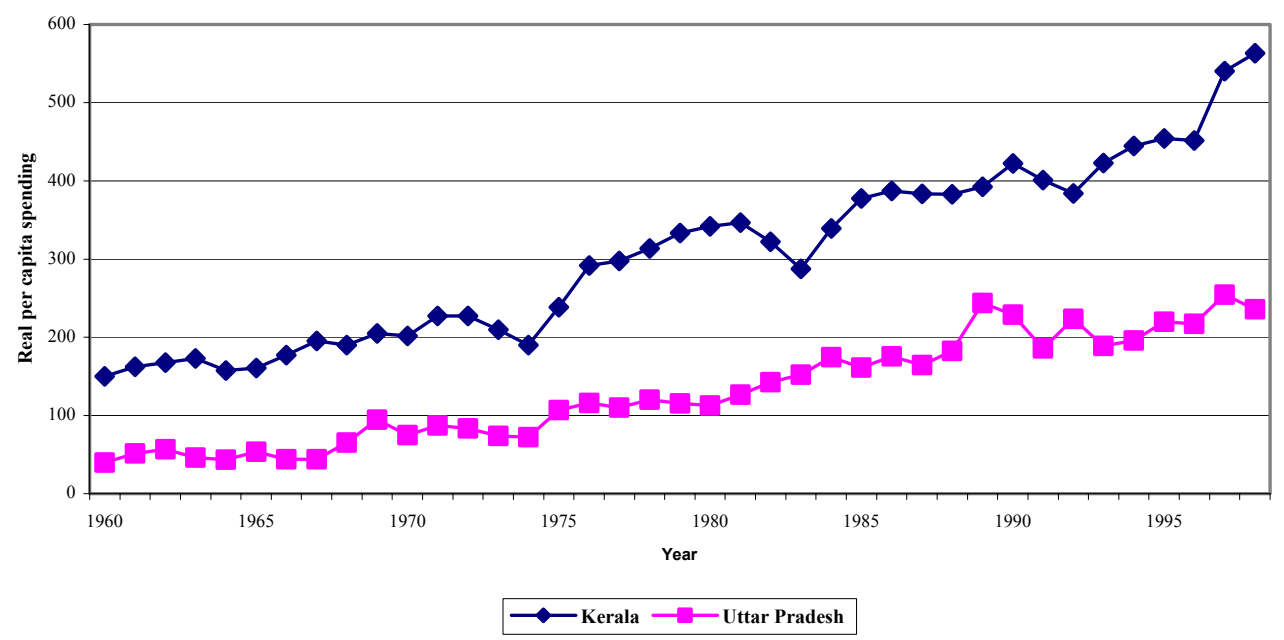

Source: For nominal public expenditures, Reserve Bank of India Bulletin, various issues. Public spending data refers to spending on the current account, the largest category of state government expenditures which includes the bulk of spending on health and education. Price deflator and population from World Bank India Poverty Database (Ozler, Datt, and Ravallion 1996). 
Figures $2 \mathrm{a}$ and $2 \mathrm{~b}$ show spending on health and education and spending on state administration alone (on the overall organs of the state, interest payments, pensions, etc., that is, exclusive of spending on public services) as a proportion of total expenditures in the two states since 1960 to 1998. Kerala started out in the early decades of electoral competition investing more than three times the proportion of its public resources in social services compared to UP. Largely because of the growing debt burden in both states which increased the share of resources going towards interest payments (included under state administrative spending), they have converged to similar levels of spending, in proportional terms, in recent years.
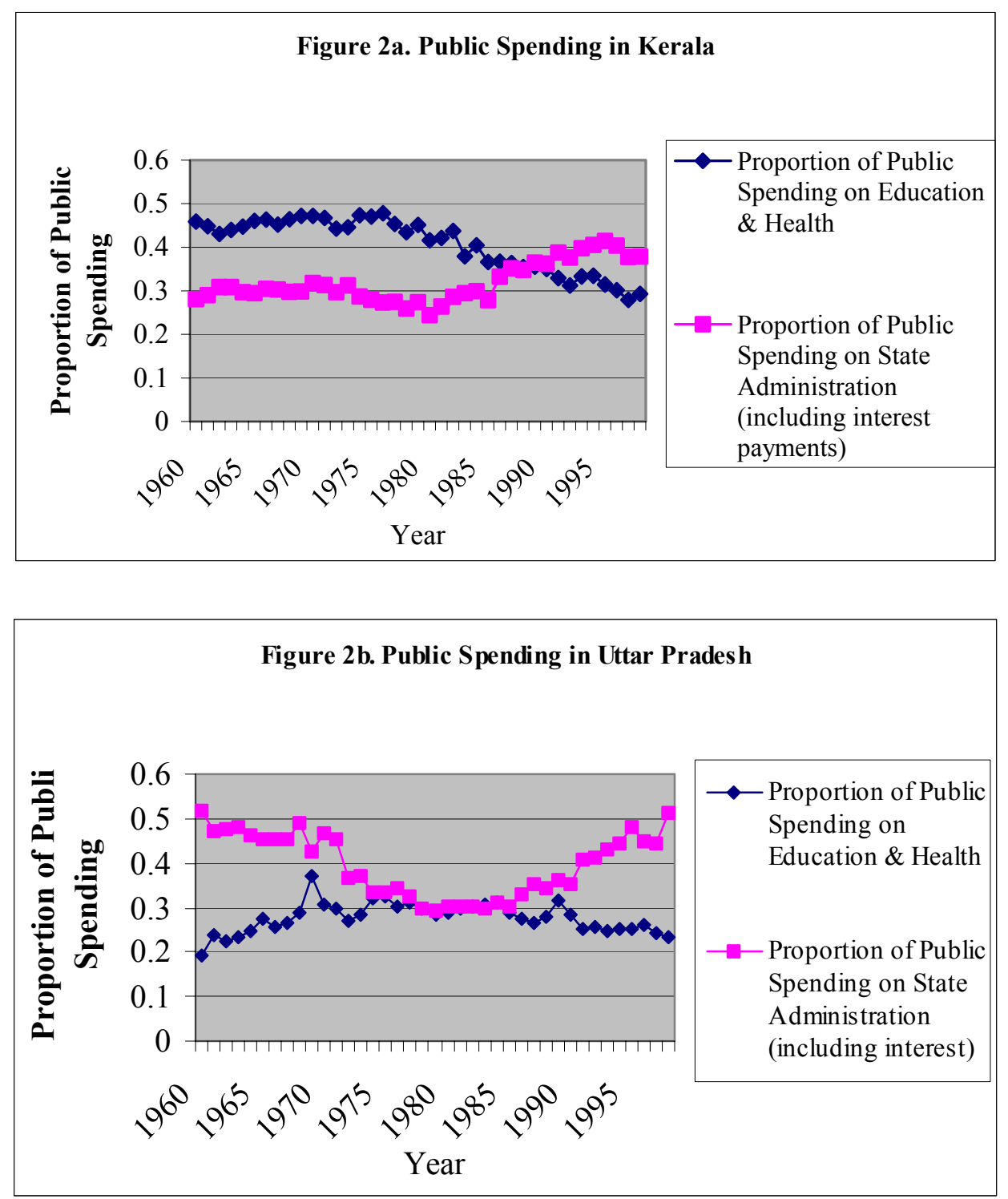

Source: Reserve Bank of India Bulletin, various issues. Public spending data refers to spending on the current account, the largest category of state government expenditures which includes the bulk of spending on health and education. 
If spending on health and education is less easy to target than other types of spending, as seems to be the case, then the allocation differences across the two states reflect stronger preferences in UP for targeted spending. The quality of public services is indisputably harder to target and here the evidence is clear: the quality and effectiveness of public spending are higher in Kerala. Drèze and Sen review extensive evidence that public schools and health clinics in Kerala have high teacher and physician attendance, are well supplied, adequately maintained, and widely utilized; similar facilities in UP simply lie abandoned.

Why? The formal political and legal institutions in the two states are the same and both states lie within a single sovereign nation. Both have had regular elections to their legislative assemblies since the 1950s, monitored by the Election Commission of India and in accordance with constitutional procedures. Hence the answer cannot lie in differences between political institutions per se, but in the dynamics of political competition. Specifically, and consistent with the discussion in the first part of this paper, Kerala's voters are better informed and less polarized on non-policy dimensions than voters in UP, and its political parties compete on credible platforms for delivering broad social services, as compared to clientelist platforms in UP.

Kerala entered the era of democratic elections with a substantially literate, informed, and politically active electorate. In contrast, the state of UP entered the new era of democracy with a population of largely illiterate voters with limited access to widely published information, and active institutions of social discrimination which effectively prevented the so-called "backward castes" from accessing public services, or perhaps from participating in political processes. Although caste issues also existed in Kerala, poor and socially disadvantaged voters were more likely to participate in political processes to influence policy issues affecting their welfare (Nossiter 1982; Chander 1986).

These differences affected political party competition and the likelihood that credible political competitors would emerge to contest elections. Following independence from British colonial rule, the Congress Party was the dominant party in India; it had the widest national presence, the most solid reputation, related to its association with the fight for independence, and the longest presence as a political party. Congress espoused a common socialist platform throughout India, focusing on state-led development and redistribution to the poor. However, at the state level there was substantial variation in the perception of the Congress Party by voters, the extent and nature of competition confronting the Congress Party, and the types of credible promises to voters that the party could or had to make to be successful.

In many states, such as in UP, Congress did not confront vigorous competition from credible and well-organized parties. In others, credible challenges to the Congress were mounted by regional parties and newly emerging communist parties. In Kerala, the 
communist parties were particularly active and invested substantially in mobilizing the poorest voters, and by repeatedly interacting with these voters, developed the ability to make credible promise to them (Chander 1986; Nossiter 1982). Competition in Kerala was therefore between two credible political parties, the Congress and communist parties, both able to make promises to broad segments of society. This diminished the importance of patron-client relationships, to an extent that was unparalleled in any other state.

In UP, on the other hand, massive voter illiteracy suggests that voters were also poorly informed about the connection between political decisionmaking and their wellbeing. This undermined the ability of any party to make credible promises to voters, since reputation with voters is difficult to establish if voters are poorly informed. Moreover, in conditions of visible and often coercive social discrimination, organization of the victims of discrimination was in any case highly costly. Drèze and Gazdar (1996) recount how a village school in UP can be non-functional for as long as ten years due to teacher absenteeism and shirking, without any collective protest being organized. Mencher (1980), on the other hand, describes how in Kerala, if a primary health center were to be unmanned for a few days, there would be massive demonstrations at the nearest district office, with people demanding redress.

Perhaps as a reflection of more informed voting along policy dimensions in Kerala, and greater credibility of political parties, voter turnout in the state has been historically higher than in any other state, averaging over 75 percent even in the first few state elections. In contrast, turnout in UP in the first few elections averaged 55 percent, which is suggestive of greater voter apathy to policy issues, because of the combination of lack of information, greater social polarization, and lack of credibility of political parties.

On the one hand, then, the Congress Party could not make credible promises related to its socialist platform of redistribution to the poor in UP. On the other hand, given the absence of challengers, there was no political payoff to the Congress Party from making such promises. In fact, the Congress party won on average more than 70 percent of the seats in the state assembly (numbers based on data provided in Butler, Lahiri, and Roy 1995). In Kerala, the payoff to broad public good promises was high, both because competing political parties could make them credibly, and because neither party could offer the same level of benefits to broadly mobilized constituents through expensive, targeted programs that they could offer through broad-based, high quality service provision. In UP, there was little political payoff to competing on the basis of broad public goods or redistributive programs; narrow, targeted goods and services, despite their limited impact on welfare, were politically superior.

Spending decisions in the early years following independence are also consistent with the absence of parties able to make credible promises to large fractions of the voting population in Uttar Pradesh. As Figures 2a and 2b show, Kerala's public resources were overwhelmingly allocated to education and health services in the early decades of democracy, 
constituting 45 percent of total expenditures, with correspondingly fewer resources (less than 30 percent) spent on state administration (largely, jobs going to non-service providers). In UP, during this same period, expenditures were concentrated in state administration, comprising almost 50 percent of the total, while health and education received less than 25 percent of public resources.. The circumstances in Kerala distinguished it as well from most Indian states, since on average the major Indian states spent approximately 30 percent of total spending on health and education and over 40 percent on state administration.

Moreover, expenditures in Kerala were effective-politicians made promises and had to keep them. The first two decades of elected state government saw dramatic improvements in human development indicators. Infant mortality declined about 43 percent, for instance, between 1956 and 1966 (Krishnan 1991). This decline has largely been attributed to high female literacy (which was also expanding through state programs in education) but was clearly facilitated by access to public primary health care, and state-sponsored programs of infant and child immunization (Zachariah 1992). Early political success in delivering high quality public health and education bolstered the credibility of political promises in this area and allowed electoral competition on the platform of social service provision to be sustained. No such progress or evolution was evident in Uttar Pradesh, where absenteeism and other indications of widespread shortfalls in service delivery suggest that even those resources spent on education and health were largely another font of political patronage, in the form of targeted jobs for teachers and health workers.

UP is not immune to the fact that it is only one state in a country with welldeveloped democratic institutions; these have slowly penetrated the social landscape in the state over the past fifty years, especially through the political mobilization of traditionally repressed lower castes. However, the pattern established early on in UP has proven difficult to change. Although new parties could, in principle, have attempted to establish state-wide policy reputations, this is costly in social environments such as that in UP, where incumbents have many tools at their disposal to block such entry. Ethnic or caste links to political candidates are the only connections that voters in UP believe will give them access to state resources. As a consequence, new political parties have organized along caste lines and compete on explicitly clientelist platforms — on the basis of narrow, targeted promises, the only promises that are politically useful in such an environment.

Among the three main parties competing in the state today, the Bharatiya Janata Party (BJP) appeals to upper caste Hindus, the Bahujan Samaj Party (BSP) to so-called backward castes, scheduled castes and tribes, and minority religion groups (hence the complementary set to upper caste Hindus), and the Samajwadi Party (SP) to similarly marginalized groups along the lines of religion and caste. Clientelist politics in Uttar Pradesh is well illustrated by the BSP platform, currently the dominant political party in the state legislature. The party simply does not print any election manifesto to explain its platform. It does, however, publicize the ethnic profile of its candidate list to demonstrate commitment 
to its single point program of proportional representation for every ethnic group in the bureaucratic institutions of the state (Chandra 1999).

This example of the contrast between Kerala and UP demonstrates that the same formal institutions of democracy can sustain very different forms of electoral competition with substantial impact on the quality of public services supported by the state. Policy interventions and electoral institutions that change the information processing capacity of voters, impact ideological fragmentation, and the capacity of politicians to make credible commitments, can potentially make a significant difference for the process of political competition and hence for the provision of broad social services. Further research is needed to evaluate the impact of ongoing political and institutional reforms in the developing world, and to draw lessons from the existing variation in institutions across countries. Where poor voters are already active in political processes the real issue is that of bolstering the credibility of political candidates to provide broad social services, with a corresponding reduction in existing political pressures to pursue clientelist policies.

\section{Conclusion: Policy Implications and Further Research}

As the Millennium Development Goals make clear, development policy has turned ever more emphatically to a focus on improving the condition of the poor. Essential to that effort are the quality and quantity of social services provided to the poor by governments. At the same time, and in parallel, there is an increasing awareness that "institutions matter" for development. Moreover, recent, extensive and rigorous work by social scientists has revealed a great deal about the impact of electoral competition and a broad array of political and electoral institutions on policy outcomes. In this paper, we attempt to join these two parallel lines of argument to answer the question: what impact does electoral competition and political decisionmaking have on social service outcomes to the poor?

Theory and evidence suggests that the impact is large, and largest for those social services such as education and health that are most important to the poor. Information gaps, social polarization and the absence of credible political competitors lead to the underprovision of government services to the least informed, to the most polarized and to the vast majority who do not have personal connections with a powerful patron.

Though there are many important efforts experimenting with different ways to improve the ability of the poor to secure their own interests in government decisionmaking, to "empower" them, the design of these typically does not explicitly address the underlying political market imperfections. Legislative reservations for minority groups in India, decentralization in Pakistan, and participatory budgeting in Brazil, for example, are all most effective to the extent that they overcome the underlying political market imperfections that notably impair governments services to the poor. As the earlier discussion of the effects of 
reservations in India suggests, the improvements wrought by these reforms may be only partial to the extent that they leave unchanged many aspects of the political marketplace.

Two types of decentralization, in particular, are often seen as responses to inadequate central government attention to social service delivery. The political economy analysis here has implications for both: decentralization of responsibilities for the provision of local public goods to the level of locally elected village and municipal governments; and greater autonomy of decision-making at the level of service providers such as schools and clinics, with greater participation of citizens through community based organizations such as parent-teacher associations and health committees.

For decentralization to have a positive impact on social services, the following conditions must be satisfied—one, voters must be more likely to use information about the quality of local public goods in making their voting decisions for local elections; and two, political promises to voters at large must be more credible, than when decision-making over local public goods was in the hands of regional or national governments. Theoretically, the impact of decentralization on informed voting and political credibility can go in either direction. Voters may use more information about local public goods in their voting decisions because such information is easier to come by and coordinate upon, perhaps given a more restricted set of responsibilities and greater observability of actions of local governments; and political agents may have greater credibility because of proximity to the community and reputation developed through social interaction over an extended period of time.

On the other hand, local voters may be apathetic to local elections and have little or no information about the resource availability and capability of local governments, if resources are concentrated in higher tiers of government; social polarization may be more intense at more local levels due to age-old differences across settled communities, and perhaps weaker at the national level owing to national campaigns of nation-building; and clientelist promises to a few voters may be easier to make and fulfill due to closer social relations between the elected representatives and their clients (see Keefer, Narayan and Vishwanath 2003, for a more extensive discussion of these issues).

Decentralization right down to the level of service providers and communities may potentially address the problem of credibility of elected political agents. Remotely located political agents are not able to credibly promise to improve quality of services in such transactions-intensive sectors such as health and education, where the quality of provision depends critically on day-to-day provider behavior, at most only committing to providing infrastructure, equipment, and salaries. If education service delivery responsibility is completely centralized, for example, then the problem of political credibility in monitoring providers may lead to empty school buildings and absent teachers, where school construction is useful for political kick-backs, and teacher posts for extending political patronage, with otherwise poor incentives for improving the quality of schooling. But if 
decentralized user monitoring of providers is institutionalized, then voters need only verify whether political agents have made resources available for schools and clinics in order to decide whether to reward or punish them at election times. ${ }^{15}$

Additional and complementary efforts can improve outcomes in areas where decentralization or other existing reforms might fall short. For example, few reforms systematically correct the political market distortions due to information. Such a reform would, for example, provide independent validation about the quality of public goods and the scope of accomplishment and failure of individual political decisionmakers. In wellestablished democracies, competing and credible political parties provide this oversight. In addition, and more usefully in less-developed democracies, the press can provide validation, but so also can external agencies and civic groups or "civil society." Survey instruments, such as citizen report cards that consolidate public feedback on the state of government services, are potentially powerful vehicles for mobilizing voters around the issue of quality of public services, although their impact is yet to be evaluated rigorously.

Credibility, like information, is particularly likely to be problematic in developing countries and also requires special attention. Here the key is to bring together two key strands of assistance to countries; one strand, by far the most important, to provide support for better education or health outcomes, and the other strand, to support political party development and the development of political institutions. These strands are brought together when outside interventions that help politicians both implement and take credit for broad public good improvements can lead to sustainable improvement in public good provision, if they help politicians build a reputation for performance. This is challenging - it means specifically that aid be provided for education and health especially in those cases where politicians have made emphatic, public and verifiable promises regarding health and education, which is not common in many developing democracies.

Finally, social polarization can have harmful effects on social service provision, just as on other aspects of civic life. One response of outside intervention is to insist that criteria other than those related to social cleavages determine access to resources. This may not be practical; for example, if one group is poorer than the other, redistributional transfers on the basis of income will always favor that group. Other responses depend on the sources of polarization.

The response to pure taste-based affiliations (voting systematically for the representatives of one particular ethnic group or tribe out of an exogenous and strong preference for anyone from that group or tribe over any other candidate) demands educational responses to moderate these tendencies. Strong signals from the center about the inappropriateness of such behavior or preferences can, over time, soften them, if not

15 This solution is limited to the extent that central government intervention is needed either to remedy disparities in performance or funding across jurisdictions, however. 
eliminate them entirely. However, if polarization is due to tremendous imperfections in political and economic markets, as is more often the case, so that people retreat into the groups with which they have the strongest personal links and the greatest hope of accessing resources, the appropriate response is to assist in reforms that remove those imperfections.

The understanding of political market imperfections reflected in this paper is a product of recent literature. Less is known about which reforms can feasibly correct these imperfections. A natural and important agenda for future research therefore falls out of this discussion. For example, understanding the impact of decentralization reforms (which institutional designs work and which do not), is an empirical issue. Since most of the reforms across countries with very different historical and institutional backgrounds is only just beginning to be implemented, there is a tremendous opportunity to rigorously evaluate the impact of different institutional designs on both actual outcomes, in terms of quality of public goods, and on the process of political competition so that lessons can be applied to very different institutional contexts across the world.

Similarly, there are examples of particular experiences from around the globe of how "information campaigns" regarding public services have succeeded. However, we have no evidence for whether instruments of this kind significantly and systematically alter the nature of political competition. Further research would be valuable on the nature of information availability and processing by poor voters, and how information provision mechanisms can be institutionalized to enable these voters to provide stronger incentives for politicians to improve performance of public services. ${ }^{16}$

Finally, more, innovative research is required on the impact of credibility on policy outcomes. Under what conditions do politicians move from promising only targeted transfers, as in most developing democracies, to broad and continuous improvements in service quality (for example, as evidenced by debates in the United States over national testing of all students in public schools)? Even unpacking the basic notion of "credibility" and understanding its process of change remains an important area for further inquiry. The rewards to such research, however, are likely to be enormous, since it would vastly improve our understanding of distressingly vast differences in government performance around the world.

16 Evidence concerning the role of the media naturally gives rise to the question: under what conditions is free (or low cost) media informative? Several authors have examined the conditions of competition in political and economic markets and the resulting incentives for the kind and quantity of information disseminated by the media industry (Strömberg 2002; Djankov and others 2003; Mullainathan and Shliefer 2002). 


\section{References}

The word "processed" describes informally reproduced works that may not be commonly available through library systems.

Alderman, H. (1998). "Estimates of consumer price response in Pakistan using market prices as data." Pakistan Development Review 27(2): 89-107.

Alesina, A., R. Baqir, and W. Easterly. (1999). "Public Goods and Ethnic Divisions". The Quarterly Journal of Economics 114(4): 1243-84.

Banerjee, A., and R. Somanathan. (2001). "Caste, Community and Collective Action: The Political Economy of Public Good Provision in India." Department of Economics, MIT. Processed.

Baron, David P. (1994). "Electoral Competition with Informed and Uninformed Voters." American Political Science Review 88 (March): 33-47.

Bates, R. (1981). Markets and states in tropical Africa: The political basis of agricultural policies. Berkley: University of California Press.

Beck, Thorsten, George Clarke, Alberto Groff, Philip Keefer, and Patrick Walsh. (2001). "New Tools in Comparative Political Economy: The Database of Political Institutions." World Bank Economic Review 15(1): 165-176.

Bertrand, M., and S. Mullainathan. (2001). "Are CEOs Rewarded for Luck? The Ones Without Principals Are.” Quarterly Journal of Economics 116(3): 901-32.

Besley, T., and R. Burgess. (2003). "The Political Economy of Government Responsiveness: Theory and Evidence from India". Quarterly Journal of Economics, Forthcoming

Betancourt, R., and S. Gleason. (2000). "The Allocation of Publicly Provided Goods to Rural Households in India: On Some Consequences of Caste, Religion and Democracy." World Development 28(12): 2169-82.

Block, S. A. (2002). "Political business cycles, democratization, and economic reform: the case of Africa." Journal of Development Economics 67: 205-28.

Butler, D., A. Lahiri, and P. Roy. (1995). India Decides: Elections 1952-1995. New Delhi: Books \& Things.

Campbell, A., P. Converse, W. Miller, and D. Stokes. (1966). The American Voter. New York: J. Wiley \& Sons.

Chander, Jose N., ed. (1986). Dynamics of State Politics in Kerala. New Delhi: Sterling Publishers.

Chandra, K. (1999). "The Ethnification of the Party System in Uttar Pradesh and its Consequences." In R. Ramashray and P. Wallace, eds., Indian Politics and the 1998 Elections: Regionalism, Hindutva, and State Politics. London: Sage Publications.

Chappell, H., and W. Keech. (1990). "Citizen Information, Rationality, and the Politics of 
Macroeconomic Policy". In John Ferejohn and James Kuklinski, eds., Information and Democratic Processes. Urbana and Chicago: University of Illinois Press.

Clague, Christopher, Philip Keefer, Stephen Knack, and Mancur Olson. (1996). "Property and Contract Rights under Democracy and Dictatorship." The Journal of Economic Growth 1(2, June): 243-76.

Djankov, Simeon, Caralee McLiesh, Tatiana Nenova, and Andrei Shliefer. (2003). "Who Owns the Media?" Journal of Law and Economics, Forthcoming (October)

Drèze, Jean and Amartya Sen (1995). India: Economic Development and Social Opportunity. Delhi: Oxford University Press. (1996). Indian Development: Selected Regional Perspectives. Delhi: Oxford University Press.

Drèze, Jean, and Haris Gazdar. (1996). "Uttar Pradesh: The Burden of Inertia”. In J. Drèze and A. Sen, eds., Indian Development: Selected Regional Perspectives. Delhi: Oxford University Press.

Easterly, W., and R. Levine. (1997). “Africa's Growth Tragedy: Policies and Ethnic Divisions." The Quarterly Journal of Economics 112(4): 1203-50.

Ferejohn, John. (1986). “Incumbent performance and electoral control.” Public Choice 50: $5-26$.

. (1990). "Information and the Electoral Process". In John Ferejohn and James Kuklinski, eds., Information and Democratic Processes. Urbana and Chicago: University of Illinois Press.

Ferejohn, John, and James Kuklinski. (1990). Information and Democratic Processes. Urbana and Chicago: University of Illinois Press.

Feyzioglu, Tarhan, Vinaya Swaroop, and Min Zhu. (1998). "A Panel Data Analysis of the Fungibility of Foreign Aid.” World Bank Economic Review 12(1, January): 29-58.

Fiorina, M. (1990). "Information and Rationality in Elections". In John Ferejohn and James Kuklinski, eds., Information and Democratic Processes. Urbana and Chicago: University of Illinois Press.

and K. Shepsle. (1990). “A Positive Theory of Negative Voting”. In John Ferejohn and James Kuklinski, eds., Information and Democratic Processes. Urbana and Chicago: University of Illinois Press.

Foster, A., and M. Rosenzweig. (2001). "Democratization, Decentralization, and the Distribution of Local Public Goods in a Poor Rural Economy." Working Paper, Brown University. http://adfdell.pstc.brown.edu/papers/democ.pdf

Gazdar, Haris. (2000). “State, Community, and Universal Education: A Political Economy of Public Schooling in Rural Pakistan." Asia Research Centre, London School of Economics (October). Processed.

Glaeser, E., and A. Shliefer. (2002). "The Curley Effect". NBER Working Paper No. 8942. National Bureau of Economic Research, Cambridge, Mass.

Glewwe, Paul, and Hanan Jacoby. (1994). "Student Achievement and Schooling Choice 
in Low-Income Countries: Evidence from Ghana.” The Journal of Human Resources 29(3): 843-64.

Grossman, G., and E. Helpman. (1996). "Electoral competition and special interest politics." Review of Economic Studies 63: 265-86.

Hungerford, Thomas, and Gary Solon. (1987). "Sheepskin Effects in the Returns to Education." Review of Economics and Statistics 69(1): 175-77.

Iyengar, S. (1990). "Shortcuts to Political Knowledge: The Role of Selective Attention and Accessibility." In John Ferejohn and James Kuklinski, eds., Information and Democratic Processes. Urbana and Chicago: University of Illinois Press.

Keefer, Philip. (2002a). "The political economy of public spending decisions in the Dominican Republic: credibility, clientelism and political institutions." Report prepared for the Public Expenditure and Institutional Review, The Dominican Republic. World Bank, Washington, D.C.

(2002b). "Clientelism, Credibility, and Democracy." Development Research Group, World Bank. Processed.

and Stephen Knack (2002). "Boondoggles and Expropriation: Rent-seeking and Policy Distortion when Property Rights are Insecure.” Policy Research Working Paper 2910 (October). World Bank, Washington, D.C.

Keefer, Philip, Ambar Narayan, and Tara Vishwanath. (2003). "The Political Economy of Decentralization in Pakistan.” Development Research Group, World Bank, Washington, D.C. Processed.

Khemani, Stuti. (2003) "Political Cycles in a Developing Economy: Effect of Elections in the Indian States." Journal of Development Economics, forthcoming.

Knack, Stephen, and Philip Keefer. (1997). "Does Inequality Harm Growth Only in Democracies? A Replication and Extension." American Journal of Political Science 41(1, January): 323-32.

Krishnan, T. N. (1991) “Kerala's Health Transition: Facts and Factors.” Center for Population and Development Studies, Harvard University. Processed.

Layard, Richard, and George Psacharopoulos. (1974). "The Screening Hypothesis and the Returns to Education." Journal of Political Economy 82(5): 985-98.

Mani, A., and S. Mukand (2002). "Democracy, Visibility and Public Good Provision". Williams College and Tufts University. Processed.

Mayhew, David. (1974). Congress: The Electoral Connection. New Haven: Yale University Press.

Meltzer, A., and S. Richard, (1981). "A Rational Theory of the Size of Government". Journal of Political Economy 89(5): 914-27.

Mencher, Joan. (1980). “The Lessons and Non-lessons from Kerala." Economic and Political Weekly, Special Number, 1781-1802.

Miguel, E. (2001). "Ethnic Diversity and School Funding in Kenya." Working Paper C01-119, Center for International and Development Economics Research, 
University of California, Berkeley.

Mullainathan, S., and A. Shliefer. (2002). "Media Bias.” Harvard Institute Research Working Paper No. 1981, and MIT Department of Economics Working Paper No. 02-33.

Nossiter, T. J. (1982). Communism in Kerala : A study in political adaptation. Delhi: Oxford University Press.

Ottati, V., and R. Wyer (1990). "The Cognitive Mediators of Political Choice: Towards a Comprehensive Model of Political Information Processing." In John Ferejohn and James Kuklinski, eds., Information and Democratic Processes. Urbana and Chicago: University of Illinois Press.

Ozler, B., G. Datt, and M. Ravallion. (1996). "A database on poverty and growth in India.” Development Research Group, World Bank, Washington, D.C. Processed.

Pande, Rohini. (2003). "Can Mandated Political Representation Increase Policy Influence for Disadvantaged Minorities? Theory and Evidence from India." American Economic Review, Forthcoming

Persson, Torsten, and Guido Tabellini. (2002). "Do Political Institutions Shape Economic Policy?" Econometrica 70: 883-905. .(2000). Political Economics: Explaining Public Policy. Cambridge, Mass.: MIT Press.

Plott, Charles. (1967). "A Notion of Equilibrium and its possibility under Majority Rule." American Economic Review 57: 787-806.

Prasad, K., and V. Eswara. (1987). Wastage, Stagnation, and Inequality of Opportunity in Rural Primary Education: A Case Study of Andhra Pradesh. Ministry of Human Resource Development, New Delhi.

Reserve Bank of India, various issues. Reserve Bank of India Bulletin.

Robinson, James, and Thierry Verdier. (2002). "The Political Economy of Clientelism." CEPR Working Paper 3205, February.

Sanmartín, Marta. (2001). "Linearity of the return to education and self-selection." Applied Economics 33: 103-42.

Schuknecht, L. (2000). "Fiscal policy cycles and public expenditure in developing countries." Public Choice 102: 115-30.

Shi, M., and J. Svensson. (2002). "Political budget cycles in developed and developing countries" Institute for International Economic Studies, Stockholm University, Processed. http://www.iies.su.se/ $\sim$ svenssoj/pbc1.pdf

Strömberg, David. (2001) “Radio's Impact on New Deal Spending." Princeton University. Processed.

Strömberg, David. (2002) "Mass Media Competition, Political Competition, and Public Policy." Review of Economic Studies, Forthcoming.

Tilak, Jandhyala B. G. (1993). "Costs and Financing of Education in India: A Review of 
Issues, Problems, and Prospects." Center for Development Studies, Trivandrum.

Van de Walle, Dominique, and Kimberly Nead (1995). Public Spending and the Poor: Theory and Evidence. Baltimore and London: Published for The World Bank, Johns Hopkins University Press.

Weiner, M. (1991). The Child and the State in India: Child Labor and Education Policy in Comparative Perspective. Princeton: Princeton University Press.

Weiner, M., and J. O. Field. (1974). Studies in Electoral Politics in the Indian States, Delhi: Manohar Book Service.

Wolfers, Justin. (2002). "Are Voters Rational? Evidence from Gubernatorial Elections.” Research Paper 1730. Graduate School of Business, Stanford University.

World Bank. (1998). "A framework for civil service reform in Pakistan." Poverty Reduction and Economic Management, South Asia (December 15). . (2001). "Nepal: Priorities and Strategies for Education Reform." Human Development Unit, South Asia Region (July 18).

. (2002). "Poverty in Pakistan: Vulnerabilities, Social Gaps and Rural Dynamics." Poverty Reduction and Economic Management, South Asia Region (October 28).

Zachariah, K. C. (1992). Demographic Transition in Kerala in the 1980s: Results of a Survey in Three Districts. Center for Development Studies, Thiruvananthapuram and Gujarat Institute of Area Planning, Ahmedabad. 